\title{
Gross community production and metabolic balance in the South Pacific Gyre, using a non intrusive bio-optical method
}

\author{
H. Claustre ${ }^{1,2}$, Y. Huot ${ }^{1,2}$, I. Obernosterer ${ }^{3}$, B. Gentili ${ }^{1,2}$, D. Tailliez ${ }^{1,2}$, and M. Lewis ${ }^{4}$ \\ ${ }^{1}$ UPMC Univ Paris 06, UMR 7093, Laboratoire d'Océanographie de Villefranche, 06230 Villefranche-sur-Mer, France \\ ${ }^{2}$ CNRS, UMR 7093, LOV, 06230 Villefranche-sur-Mer, France \\ ${ }^{3}$ Université Pierre et Marie Curie-Paris6, UMR7621, F66650 Banyuls-sur-Mer, France ; CNRS, UMR7621, F-66650 \\ Banyuls-sur-Mer, France \\ ${ }^{4}$ Department of Oceanography, Dalhousie University, Halifax, Nova Scotia B3H 4J1, Canada
}

Received: 30 July 2007 - Published in Biogeosciences Discuss.: 03 September 2007

Revised: 7 January 2008 - Accepted: 3 March 2008 - Published: 28 March 2008

\begin{abstract}
The very clear waters of the South Pacific Gyre likely constitute an end-member of oligotrophic conditions which remain essentially unknown with respect to its impact on carbon fixation and exportation. We describe a nonintrusive bio-optical method to quantify the various terms of a production budget (Gross community production, community losses, net community production) in this area. This method is based on the analysis of the diel cycle in Particulate Organic Carbon (POC), derived from high frequency measurements of the particle attenuation coefficient $c_{p}$. We report very high integrated rates of Gross Community Production within the euphotic layer (average of $846 \pm 484 \mathrm{mg} \mathrm{C}$ $\mathrm{m}^{-2} \mathrm{~d}^{-1}$ for 17 stations) that are far above any rates determined using incubation techniques for such areas. Furthermore we show that the daily production of POC is essentially balanced by the losses so that the system cannot be considered as net heterotrophic. Our results thus agree well with geochemical methods, but not with incubation studies based on oxygen methods. We stress to the important role of deep layers, below the euphotic layer, in contributing to carbon fixation when incident irradiance at the ocean surface is high (absence of cloud coverage). These deep layers, not considered up to know, might fuel part of the heterotrophic processes in the upper layer, including through dissolved organic carbon. We further demonstrate that, in these extremely clear and stratified waters, integrated gross community production is proportional to the POC content and surface irradiance via an efficiency index $\psi_{\mathrm{GCP}}^{*}$, the water column cross section for Gross Community Production. We finally discuss our results in the context of the role of oligotrophic gyre in the global
\end{abstract}

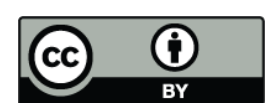

Correspondence to: H. Claustre (claustre@obs-vlfr.fr) carbon budget and of the possibility of using optical proxies from space for the development of growth community rather than primary production global models.

\section{Introduction}

Subtropical gyres are vast oceanic oligotrophic biomes representing $60 \%$ of the global ocean. Their metabolic state (magnitude of carbon fixation vs. respiration rates) and, consequently, their role in the global oceanic carbon cycle is still being debated (del Giorgio et al., 1997; Williams, 1998) which finds its roots in early discussions about the magnitude of carbon fixation in these systems (Jenkins, 1982; Lewis et al., 1986; Jenkins, 1988). On one hand, and based on in vitro biological techniques performed in the euphotic zone and having characteristic time scales of $\sim 1$ day, it is generally concluded that the ocean is in a net heterotrophic state: rates of carbon fixation are low and the whole community respiration rate $(\mathrm{R})$ exceeds the gross primary production (GPP) (del Giorgio et al., 1997; del Giorgio and Duarte, 2002), so that the so-called Net Community Production $(\mathrm{NCP}=\mathrm{GPP}-\mathrm{R})$ is always negative. On the other hand, studies based on geochemical tracer distributions with larger relevant space/time scales support net production and export rates one order of magnitude higher (Jenkins, 1982; Jenkins, 1988; Lewis et al., 1986; Hansell et al, 2004). As a result, the upper ocean ecosystems are considered on average to be autotrophic which suggests that in vitro experiments are affected by biases or not representative of larger space or time scales. Modelling studies conclude that mesoscale activity and the so-called eddy-pumping processes cannot explain the discrepancies between both approaches (Oschlies,

Published by Copernicus Publications on behalf of the European Geosciences Union. 


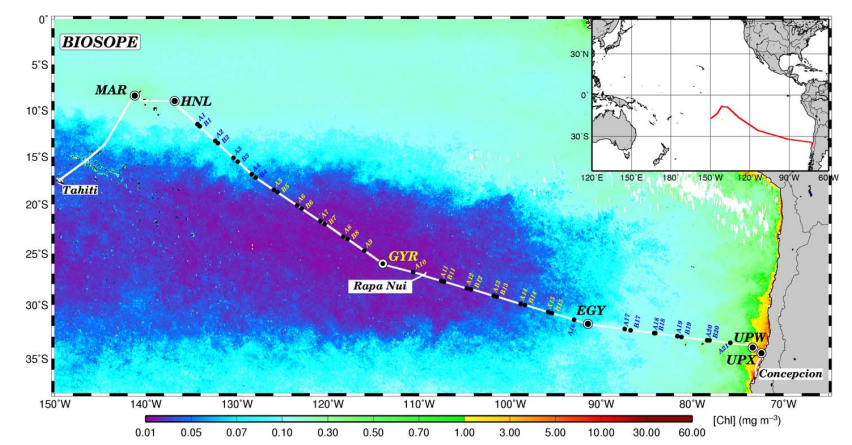

Fig. 1. Transect of the BIOSOPE cruise superimposed on a SeaWiFS composite image of Chl- $a$ concentration in the upper layer for November-December 2004.

2002), and that unaccounted biological processes, such as $\mathrm{N}_{2}$-fixation (Gruber, 2005), export of dissolved organic carbon (Dietze and Oschlies, 2005) or episodic primary production events generally missed by classical sampling strategies (Karl et al., 2003; Williams et al., 2004), may be responsible. It has been suggested that primary production rates are as much as 3-5 times higher in these vast ocean regions than what has been estimated using classical strategies/methods (Karl et al., 2003). Given the vast extent of the oligotrophic gyres, the implications for carbon dynamics at the global scale are profound.

Siegel et al. (1989) presented the first data of a daily cycle in the attenuation coefficient, $c_{p}$, a proxy of particle load, in the upper layers $(>100 \mathrm{~m})$ of the oligotrophic waters of the North Pacific Gyre. Increase of particle load was observed during daytime, while a decrease of similar amplitude was observed during nightime, allowing the conclusion that particle production was balanced at the daily scale. Since $c_{p}$ is strongly correlated with Particulate Organic Carbon (POC) concentration (e.g. Gardner et al., 1993; Loisel and Morel, 1998) it can be calibrated to retrieve the diel variations in POC. Indeed, daily cycle in $c_{p}$ must contain information about the various terms (gains, losses) involved in the upper ocean carbon budget. The seminal paper of Siegel was thus the starting point of subsequent studies where the diel cycle in $c_{p}$ and its potential implication in terms of carbon fluxes in the upper oceanic layers were addressed. Analyses of these diel variations were later performed either from shipbased acquisition (e.g. Cullen et al., 1992; Cullen and Lewis, 1995; Walsh et al., 1995; Durand and Olson, 1996; Claustre et al., 1999) from mooring data (Marra, 1994; 1995; 2002) or from laboratory culture (e.g. Stramski and Reynolds, 1993; Stramski et al., 1995; Durand and Olson, 1998; Claustre et al., 2002). Most of these studies were motivated by a strong interest in developing and using a non-intrusive method to measure biogeochemical rates whose estimation normally requires sample manipulation and incubation. To our knowledge the comparison of $c_{p}$-based production with classical incubation techniques has been carried out only once (Marra, 2002 for the North Atlantic Bloom Experiment) and they were found to provide similar estimates in this environment.

The first aim of the present study is to continue the investigation of the daily cycle in optically-resolved POC and its potential significance to quantify the various terms of the production budget. In the context of the metabolic balance of subtropical oligotrophic gyre, our study is here based on the South Pacific Gyre (SPG). This region is likely the most oligotrophic oceanic area (Claustre and Maritorena, 2003) of the global ocean with the clearest waters ever reported (Morel et al., 2007a) associated with undetectable surface nitrate and the deepest nitracline (Raimbault et al., 2008). Obviously, any conclusions reached about the carbon production terms in this oligotrophic condition end-member might constitute a reference for subtropical gyres as a whole. Therefore, as part of the BIOSOPE cruise (Claustre et al., 2008) which was carried out in the South East Pacific and crossed the SPG in its most oligotrophic part, we here focus on the analysis and interpretation of the diel cycle in $c_{p}$ for a $\sim 3000 \mathrm{~km}$ subset of the transect where the oligotrophic conditions appeared to be the most extreme.

\section{Methods}

\subsection{Cruise description and station selection}

The BIOSOPE cruise onboard RV Atalante took place during austral summer from 26 October to 11 December from the Marquesas Islands towards the Chilean coast. The $\sim 8000 \mathrm{~km}$ transect encompassed a wide range of hydrodynamic and trophic conditions (Claustre et al., 2008). Two types of stations were investigated (Fig. 1), the so-called long (more than 2 days of occupation) and short (less than one day of occupation) stations. For the present study we will mainly focus on the most oligotrophic waters. They are here defined as those waters for which the euphotic zone depth (the depth where the Photosynthetically Available Radiation (PAR, in the range $400-700 \mathrm{~nm}$ ) is reduced to $1 \%$ of its surface value) is greater than $100 \mathrm{~m}$. Actually such criteria delineates waters with surface Chlorophyll- $a$ (Chl- $a$ ) concentration lower than $\sim 0.08 \mathrm{mg} \mathrm{m}^{-3}$ (Morel et al., 2007b, equation in the legend of their Fig. 9). Such waters represent $\sim 30 \%$ of the global ocean (Antoine et al., 2005, their Fig. 8). In the area investigated during BIOSOPE, these oligotrophic stations include the long station GYR (Fig. 1), west of Easter Island. We will focus on this station to develop our approach and apply it elsewhere. From the realtime ocean color images, this station was selected as having the lowest surface Chl- $a$ concentration (see also supplementary information, part $1 \mathrm{http} / / / \mathrm{www}$. biogeosciences.net/ 5/463/2008/bg-5-463-2008-supplement.pdf). The GYR station was occupied for five days and eight casts a day were performed. Additionally, 13 "oligotrophic" short stations 
(StB2 to StB15 and StB19, Fig. 1) were investigated and at least three casts were performed during the day period.

\subsection{Particle attenuation coefficient: treatment and signifi-} cance

The attenuation coefficient, $c\left(\mathrm{~m}^{-1}\right)$ was determined using a Wetlabs C-star transmissiometer $(25 \mathrm{~cm}$ path length and $660 \mathrm{~nm}$ wavelength) attached to the CTD rosette. Each cast was performed down to $500 \mathrm{~m}$. Data treatment was performed as described in Loisel and Morel, 1998 and Claustre et al., 1999. Briefly, in order to take into account any possible variation due to change in the cleanliness of the optical window, attenuation coefficient profiles were corrected assuming that deep waters were optically stable and close to pure water $\left(c=0.364 \mathrm{~m}^{-1}\right)$. The average of attenuation coefficient between 450 and $500 \mathrm{~m}$ was thus taken as a reference for each cast.

In open ocean waters, the beam attenuation coefficient at $660 \mathrm{~nm}$ measured by a transmissiometer, once corrected for absorption by pure water, is essentially a measurement of the attenuation coefficient by particles, $c_{p}\left(\mathrm{~m}^{-1}\right)$, because absorption coefficients by dissolved material are negligible at this wavelength (Loisel and Morel, 1998). Furthermore, the absorption by particles (detrital and vegetal) is also negligible so that $c_{p}$ is equivalent to the particle scattering coefficient. Thus, the main source of variation in $c_{p}$ is the numerical abundance and size of particles while second order sources are refractive index and shape of particles (Gardner et al., 1993). For a standard particle size distribution (Junge type with a -4 exponent), the particles to which the transmissiometer is most sensitive lie in the $0.5-10 \mu \mathrm{m}$ size range (Stramski and Kiefer, 1991) which typically corresponds to the size domain of the living (pico- and nanophytoplankton, cyanobacteria, heterotrophic and photo-heterotrophic bacteria pico- and nano-zooplankton) and non-living particles (detritus). It has been suggested (Morel, 1988) and subsequently verified (e.g. Gardner et al., 1993 ; Loisel and Morel, 1998; Claustre et al., 1999) that $c_{p}$ is linearly related to the particulate organic concentration, POC $\left(\mathrm{mg} \mathrm{m}^{-3}\right)$. Some significant regional differences in this relationship have been reported. In particular a relationship with a slope of $502 \mathrm{mg} \mathrm{C} \mathrm{m}^{-3}$ $\mathrm{m}^{-1}$ was reported for the North western part of South Pacific gyre (Claustre et al., 1999) which was at least twice larger than those found for other oceanic regions (Siegel et al., 1989; Walsh et al., 1995). As part of the present study and using 35 simultaneous $c_{p}$ and POC measurements, the high slope was confirmed $\left(\mathrm{POC}=502 c_{p}+10\right)$ and also recently corroborated by new regional relationships obtained for the North Pacific Gyre (slope=560) and the equatorial Pacific (slope $=552$ ) (Gardner et al., 2006). Therefore, the slightly rounded relationship $\mathrm{POC}=500 c_{p}$ proposed by (Claustre et al., 1999) is adopted for the present study. This conversion factor is equivalent to an attenuation cross section of $2 \mathrm{~m}^{2} \mathrm{gC}^{-1}$. The relative stability of the $c_{p}$ vs. POC rela- tionship over the diel cycle is critical when dealing with the inversion of the $c_{p}$ diel cycle into carbon production terms. This aspect is investigated in more detail in supplementary information http://www.biogeosciences.net/5/463/2008/ bg-5-463-2008-supplement.pdf (part 2).

\subsection{Other measurements}

Total sun radiation was measured onboard (every min) using an Eppley pyranometer. PAR (in energy units) was subsequently derived, assuming it represents $43 \%$ of the total irradiance at the ocean surface.

For the pigment analysis, $5.6 \mathrm{~L}$ of seawater were filtered onto GF/F filters which were subsequently stored in liquid nitrogen. Within 3 months after collection, pigments were extracted in methanol and analysed by HPLC using a method dedicated for low concentration samples (Ras et al., 2008). The HPLC absorbance detector was also set at $770 \mathrm{~nm}$ to detect bacteriochlorophyll- $a$ (Bchl- $a$ ) (limit of quantitation of $0.0004 \mathrm{mg} \mathrm{m}^{-3}$ ). The euphotic zone limit, $\mathrm{Ze}(\mathrm{m})$ was derived from in situ radiometric measurements using a LICOR irradiance profiler (Morel et al., 2007a). On some occasions, when irradiances measurements were not performed, Ze was derived from the vertical profile of Chl- $a$ as described in Ras et al. (2008).

For the determination of particulate organic carbon (POC), up to $8.2 \mathrm{~L}$ of seawater were collected from Niskin bottles and filtered onto precombusted GF/F filters. Carbon Analysis was performed using a CEC 440HA Organic Elemental Analyzer after the filters had been treated with $0.25 \mathrm{ml}$ of $10 \% \mathrm{HCl}$ to remove inorganic carbon (Stramski et al., 2008).

On two occasions at the GYR station (12 November and 14 November), net community production and community respiration were measured using 24-h light and dark incubations, respectively, of unfiltered seawater in 120-ml biological oxygen demand (BOD) bottles. Seawater was collected at 6 depths in the upper $200 \mathrm{~m}$ and in situ incubations started at 06:00 a.m. The BOD bottles were filled by siphoning the seawater from 10-L acid-rinsed polycarbonate (PC) carboys, using silicon tubing and allowing the BOD bottles to overflow. Prior to sampling, the BOD bottles were rinsed with $1 \mathrm{~N} \mathrm{HCl}$, Milli-Q water and seawater $(3 \times)$ from the respective depth layer. Measurements of net community production and respiration were performed in five replicate BOD bottles. Gross primary production and community respiration were calculated as the difference between the initial and final dissolved oxygen concentrations in the light and dark incubations, respectively. The concentration of dissolved oxygen was determined by Winkler titration of whole bottles. Titration was done with an automated potentiometric end-point detection system (Metrohm DMS 716). The mean standard error of the oxygen concentration determination was $0.15 \mu$ mole $\mathrm{O}_{2}$ $\mathrm{L}^{-1}$ (coefficient of variation of $0.061 \%$ ). 

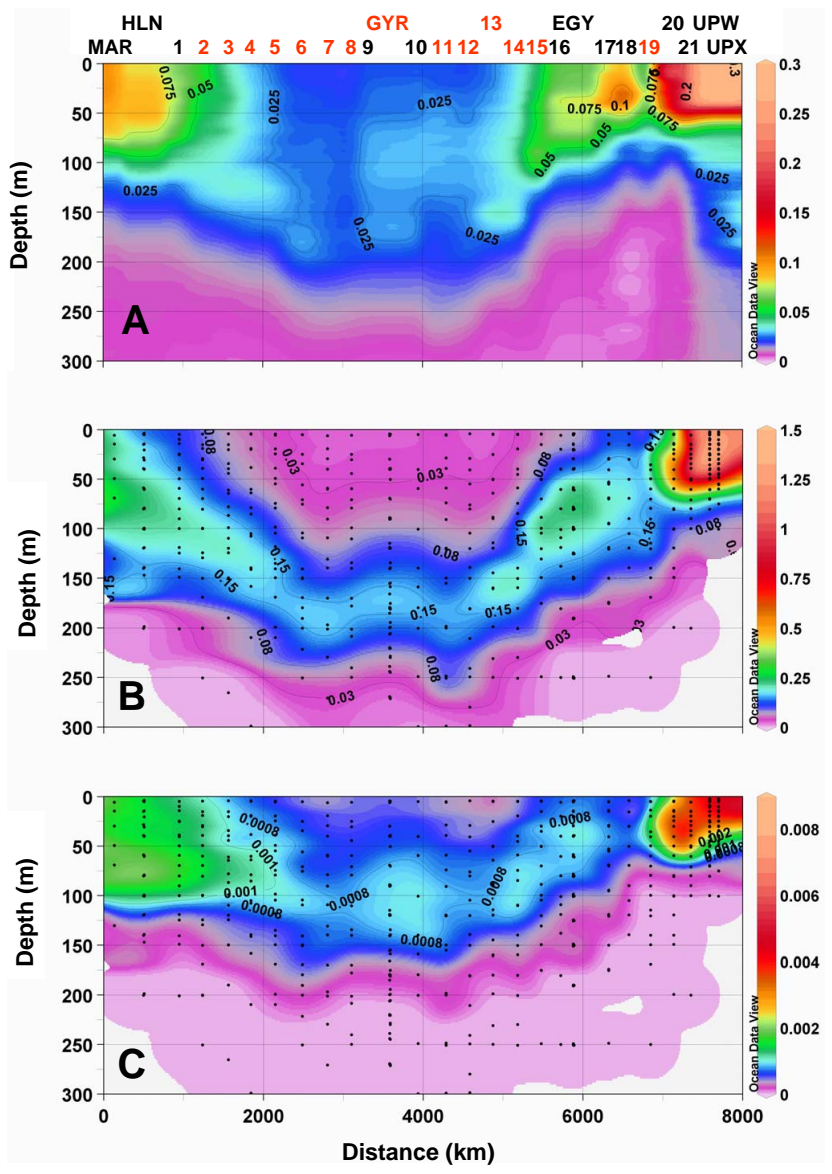

Fig. 2. Distribution of key biogeochemical quantities along the BIOSOPE transect. (a) The attenuation coefficient, $c_{p}$. (b) the concentration in Chl- $a$ (sum of mono- and Divinyl-Chl-a) (c) the concentration in bacteriochlorophyll- $a\left(\mathrm{mg} \mathrm{m}^{-3}\right)$. On the upper part of panel A are reported the positions of station (see also Fig. 1). The "oliogotrophic stations" examined in this study are identified in red.

\section{Results and discussion}

\subsection{Main patterns observed along the transect}

The main hydrodynamic patterns crossed along the BIOSOPE transect are described in detail in Claustre et al. (2008). The distribution in $c_{p}$ (Fig. 2) is in accordance with these patterns. At both extremities, in the vicinity of Marquesas islands (west) and associated with the Peru Chile Current (east), high $c_{p}$ values are recorded in the upper layers (up to $0.5 \mathrm{~m}^{-1}$ in the upwelling conditions off the Chilean coast). In the central part of transect ( $\sim \mathrm{km} 2000$ to $\mathrm{km} 4500)$, associated with undetectable nitrates in the $0-150 \mathrm{~m}$ layer (Raimbault et al., 2008), low surface Chl- $a$ and the presence of a pronounced deep Chl- $a$ maximum (DCM, sometimes extending to $180 \mathrm{~m}$ and below), $c_{p}$ takes its lowest values, especially at stations 7 and 8 . Station 7 indeed represent the clearest waters of the cruise (Morel et al., 2007a) with

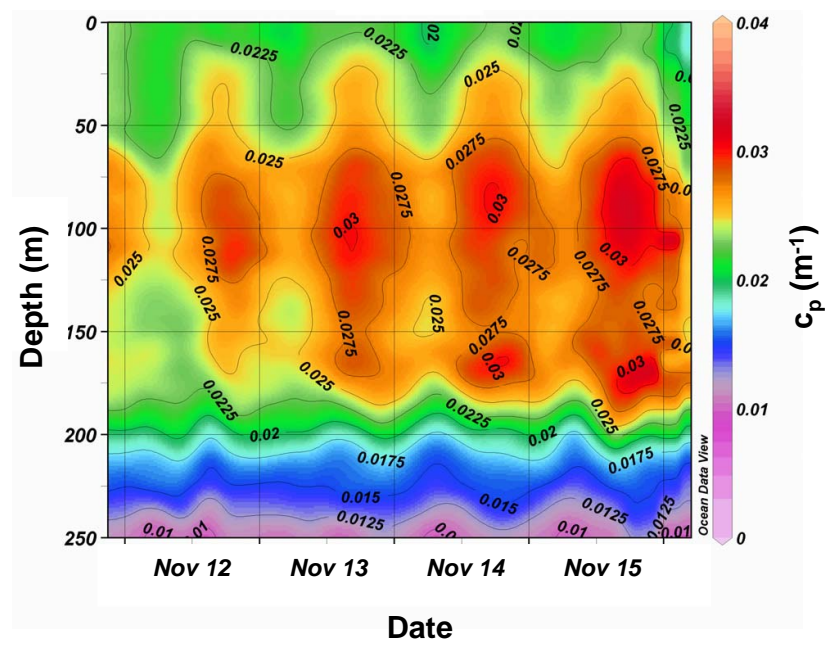

Fig. 3. Daily and vertical variations in $c_{p}$ within the $0-300 \mathrm{~m}$ layer at the GYR station.

an euphotic zone depth extending down to $\sim 170 \mathrm{~m}$. From the GYR station to St14 there is a weak, but significant, relative maximum in $c_{p}$ around $\sim 100 \mathrm{~m}$. The distribution of $c_{p}$ in this layer roughly parallels that of BChl- $a$, an indicator of photoheterotrophs performing anoxygenic photosynthesis. Eastwards, outside the core of the oligotrophic part of the Gyre, station 19 still presents oligotrophic characteristics with an euphotic zone depth of $\sim 105 \mathrm{~m}$, surface Chl- $a$ of $\sim 0.06 \mathrm{mg} \mathrm{m}^{-3}$ and $c_{p}<0.06 \mathrm{~m}^{-1}$ in the upper layer. Actually, nutrient distribution at this station $(\sim 2.8 \mathrm{mM}$ at the surface) reveals that it corresponds to a High Nutrient Low Chl- $a$ situation (Raimbault et al., 2008).

3.2 POC budget at the daily cycle: case study at the GYR station

\subsubsection{The various terms of the budget}

At the GYR station, high frequency CTD transmissiometry measurements allow the variations of $c_{p}$ to be highlighted at the daily scale (Fig. 3). $c_{p}$ measurements displayed conspicuous daily variations with a sunrise minimum and sunset maximum, an observation previously reported for other oligotrophic and mesotrophic areas (Siegel et al., 1989; Claustre et al., 1999). While this cycle was detectable down to $220-240 \mathrm{~m}$, there are two zones in the upper layer, where this cycle is stronger: the zone of the DCM and the layer around $\sim 100 \mathrm{~m}$ (zone of BChl- $a$ maximum, see Fig. 2). Once calibrated in terms of POC and integrated over pre-defined layers (POC, see Fig. 4), the clear increase of POC during the day followed by a decrease of roughly similar amplitude at night, suggests that production and loss of POC are balanced over $24 \mathrm{~h}$ (see also supplementary information, part $2 \mathrm{http} / / / \mathrm{www}$. biogeosciences.net/ 5/463/2008/bg-5-463-2008-supplement.pdf). In a less olig- 


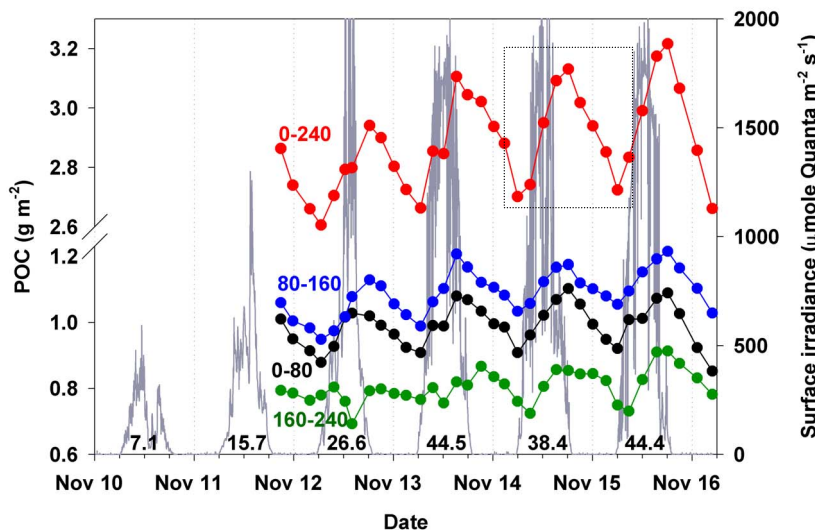

Fig. 4. Daily variations in integrated particulate organic carbon content, derived from $c_{p}$ measurements, over various optical depth intervals. Red : $0-240 \mathrm{~m}$ corresponds to the range of $100 \%-0.1 \%$ of surface irradiance; Blue : $80-160 \mathrm{~m}(10 \%-1 \%)$; Black : $0-80 \mathrm{~m}$ (100\%-10\%); Green : 160-240 m (1\%-0.1\%). Surface irradiance is plotted as a grey line and the number inside each daily irradiance cycle refers to the daily dose of photons (moles quanta $\mathrm{m}^{-2}$ ). The dotted square identifies the portion of the cycle which is used for the schematic presented in Fig. 5.

otrophic part of the South Pacific Gyre $\left(16^{\circ} \mathrm{S}, 150^{\circ} \mathrm{W}\right.$, with surface concentration of $\sim 0.07 \mathrm{mg} \mathrm{Chl}-a \mathrm{~m}^{-3}$ ), it was established that phytoplankton do not contribute to more than $20 \%$ of the POC stocks within the euphotic layer (Claustre et al., 1999), a value which was confirmed in the present study (Grob et al., 2007) throughout the gyre. While the fraction of the contribution to the total POC is low, it can be shown that growth rates typical of phytoplankton in such systems can account for a significant part of the daily variability in POC seen by the transmissiometer (see supplementary information part $2 \mathrm{http}: / / \mathrm{www}$.biogeosciences.net/5/463/2008/ bg-5-463-2008-supplement.pdf). The rest of the increase is due to other heterotrophic components (e.g. bacteria, flagellates) of the microbial community. Given that the increase in POC occurs during the day, the increase of heterotrophic biomass thus appears also stimulated (positively related) to photo-trophic processes. We thus propose that a budget of the various production and loss terms can be derived from the variations in the integrated content in POC at the daily scale (Fig. 5).

Over a given oceanic layer, the light stimulated Gross Community Production (GCP) seen by a transmissiometer ( ${ }^{\mathrm{Opt}} \mathrm{GCP}, \mathrm{mg} \mathrm{C} \mathrm{m} \mathrm{m}^{-2} \mathrm{~d}^{-1}$, the Opt prefix refers to opticallydetermined) is here defined as the sum of Gross Primary Production (GPP, excluding dissolved production) and of the production by the microbial (heterotrophic) community (which arise in part from dissolved phytoplankton production). The Net Community Production measured optically ( ${ }^{\mathrm{Opt}} \mathrm{NCP}, \mathrm{mg} \mathrm{C} \mathrm{m}^{-2} \mathrm{~d}^{-1}$ ) thus represents the difference between ${ }^{\mathrm{Opt}} \mathrm{GCP}$ and community losses ( ${ }^{\mathrm{Opt}} \mathrm{CL}, \mathrm{mg} \mathrm{C} \mathrm{m}{ }^{-2}$

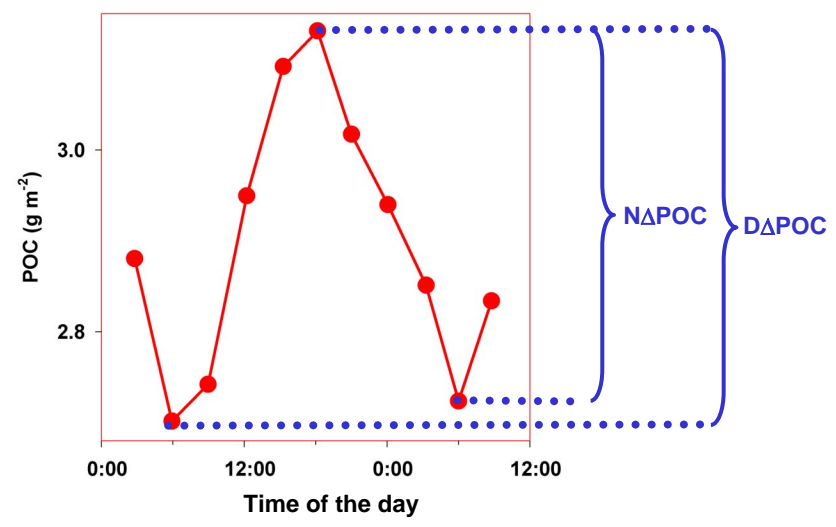

Fig. 5. Schematic of the various terms of the metabolic balance that can be inferred from the diel change in $c_{p}$ or POC. The data corresponds to the third cycle presented in Fig. 4 (dotted square).

$\left.\mathrm{d}^{-1}\right)$.

${ }^{\mathrm{Opt}} \mathrm{NCP}={ }^{\mathrm{Opt}} \mathrm{GCP}-{ }^{\mathrm{Opt}} \mathrm{CL}$

Community loss processes primarily include respiration, however, other processes such as grazing and sinking must also contribute to the removal of particles (and hence POC) measured by a transmissiometer. Because NCP is strictly defined as the difference between GCP and respiration rate and since additional loss processes are taken into account by the optical method (i.e. ${ }^{\mathrm{Opt}} \mathrm{CL},>$ respiration rate), ${ }^{\mathrm{Opt}} \mathrm{NCP}$ likely underestimates NCP. In the hyperoligotrophic conditions studied, the additional loss terms are expected to be small and the underestimation of NCP by ${ }^{\mathrm{Opt}} \mathrm{NCP}$ to be weak, if any. This is because such systems are characterized by a dominance of small particles (picophytoplankton, heterotrophic bacteria), whose grazers (e.g. nanoflagellates) are still in the size range detected by the transmissiometer (see also supplementary information, part $2 \mathrm{http} / / \mathrm{www}$. biogeosciences.net/ 5/463/2008/bg-5-463-2008-supplement.pdf). Furthermore sinking is expected to be negligible under such conditions.

For the duration of the night period $(\mathrm{Nt}, \mathrm{d})$, the Gross Community Production is null, so the night time decrease in POC, $\mathrm{N} \triangle \mathrm{POC}\left(\mathrm{mg} \mathrm{m}^{-2}\right.$, taken as a positive number), can be considered as an estimation of ${ }^{\mathrm{Opt}} \mathrm{CL}$, assumed to be the identical for the night and day period (in the same way that bacterial respiration is assumed to be constant for the $\mathrm{O}_{2}$ in vitro technique relying on $24 \mathrm{~h}$ incubation):

${ }^{\mathrm{Opt}} \mathrm{CL}=\mathrm{N} \Delta \mathrm{POC} / \mathrm{Nt}$

inserting Eq. (2) into (1):

${ }^{\mathrm{Opt}} \mathrm{GCP}={ }^{\mathrm{Opt}} \mathrm{NCP}+\mathrm{N} \triangle \mathrm{POC} / \mathrm{Nt}$

At this stage, another constraint can be imposed, which is derived from the observation of Fig. 4. Actually, over a full day, the daily increase in POC, D $\triangle \mathrm{POC}\left(\mathrm{mg} \mathrm{m}^{-2}\right)$ roughly 

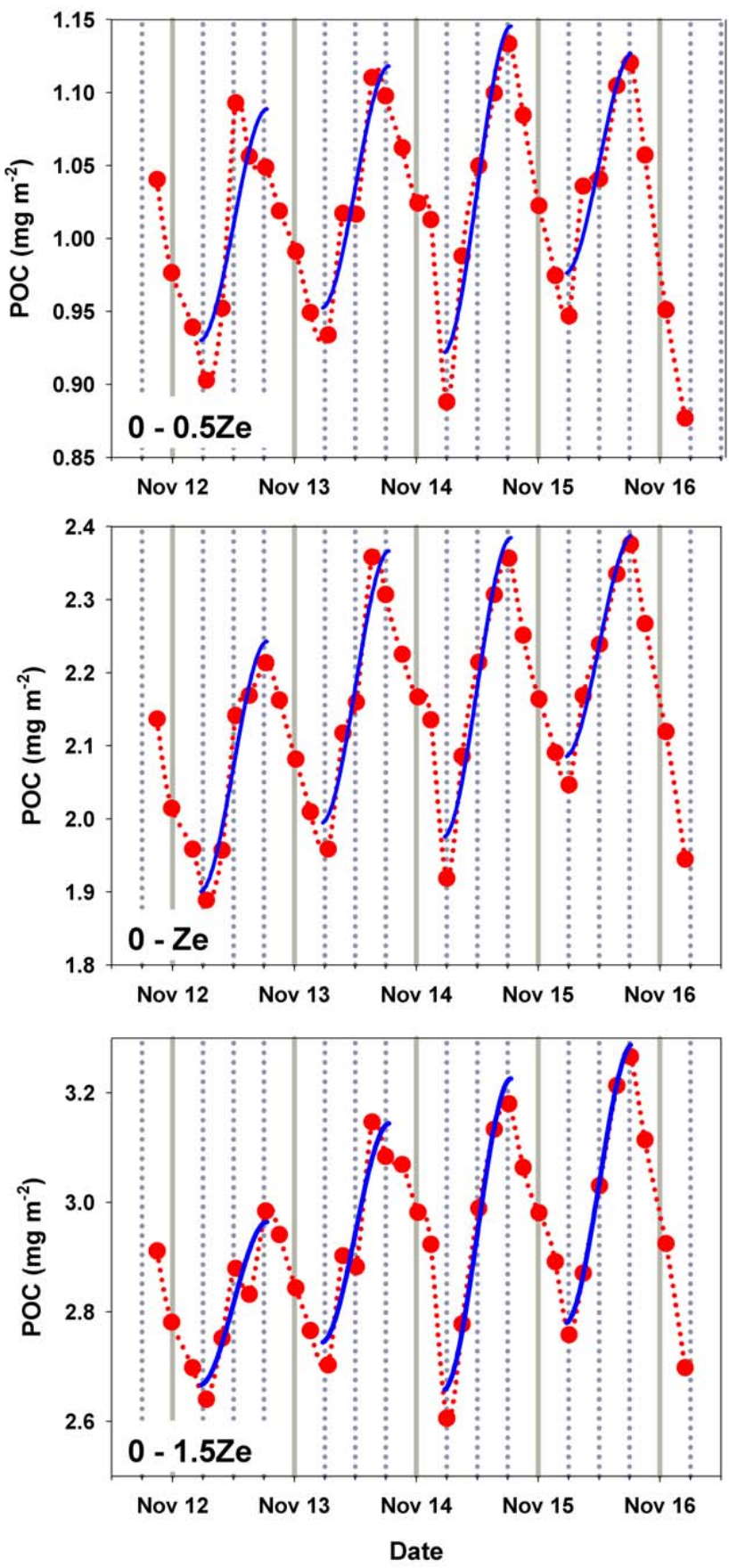

Fig. 6. Modelling diurnal variations in optically determined POC in various optical layers at the GYR station. The red dot corresponds to the data while the blue line represents the fitting of Eq. (1) to the data.

balances N $\triangle$ POC. NCP presents slight positive and negative variations from day to day at station GYR (Fig. 4). However, over the 4 days of investigation the average NCP is not significantly different from zero. This thus implies that over the four days:

$\mathrm{D} \Delta \mathrm{POC}=\mathrm{N} \Delta \mathrm{POC}$

Using this new constraint, ${ }^{\mathrm{Opt}} \mathrm{GCP}$ can be expressed as:

${ }^{\mathrm{Opt}} \mathrm{GCP}=\mathrm{D} \Delta \mathrm{POC} / \mathrm{Nt}=\mathrm{N} \Delta \mathrm{POC} / \mathrm{Nt}$

Equation (5) shows that, when the light-dark cycle is close to $12: 12(\mathrm{Nt} \sim 0.5 \mathrm{~d}),{ }^{\mathrm{Opt}} \mathrm{GCP}$ is roughly twice the loss rates. Furthermore, it shows that only the increase (or decrease) in POC during day (or night) time and the duration of the night is required to estimate ${ }^{\mathrm{Opt}} \mathrm{GCP}$. This approximation is, of course, only valid in stable systems and will only hold in systems where biomass is not changing on the daily scale (i.e. $\mathrm{D} \triangle \mathrm{POC}=\mathrm{N} \triangle \mathrm{POC}$ ).

\subsubsection{Model development}

The sampling frequency at the GYR station was sufficient to encompass the full range of day-night variations in POC. This was not the case for other stations (see Fig. 2) which were sampled only 3 times during daytime. To obtain ${ }^{O p t}$ GCP from these data, we need to provide additional information in the form of a simple model. We base this model on the rather regular daily variations in POC observed at the GYR station, which suggests that they can be accurately modelled using an empirical formulation. A polynomial of third degree was chosen with the following constraints. The rates of change of POC are equal to zero at sunrise $\left(t_{s r}, \mathrm{~h}\right)$ and sunset $\left(t_{s s}, \mathrm{~h}\right)$, respectively and maximal (inflexion point) at noon $\left(t_{n o}, \mathrm{~h}\right)$. Using these constraints, the time variation in POC, POC(t), can be modelled as:

$[\mathrm{POC}(t)]=\left[\mathrm{POC}_{t_{n o}}\right]+\mathrm{RPOC}_{t_{n o}}\left(t-t_{n o}\right)\left[\frac{1-\left(t-t_{n o}\right)^{2}}{3\left(t_{s r}-t_{n o}\right)^{2}}\right]$

where $\left[\mathrm{POC}_{t n o}\right]\left(\mathrm{mg} \mathrm{m}^{-2}\right)$ and $\mathrm{RPOC}_{t n o}\left(\mathrm{mg} \mathrm{m}^{-2} \mathrm{~h}^{-1}\right)$ represents the $[\mathrm{POC}]$ content and the instantaneous production in $[\mathrm{POC}]$ at noon $\left(t_{n o}, \mathrm{~h}\right)$, respectively. Actually, $\mathrm{RPOC}_{t n o}$ represents the maximal instantaneous rate of change in POC. Equation (6) was fitted to the GYR data using the GaussNewton method. The model performs well for the four days of investigation and for the 3 layers investigated (Fig. 6). Actually fitted ${ }^{\mathrm{Opt}} \mathrm{GCP}$ compares well with measured ${ }^{\mathrm{Opt}} \mathrm{GCP}$ estimated from the difference between the minimal and maximal values (Fig. 7).

3.3 Gross and Net Community production in oligotrophic regime

The average ${ }^{\text {Opt }} \mathrm{GCP}$ within the euphotic zone over four diel cycles is $\sim 734( \pm 97) \mathrm{mg} \mathrm{C} \mathrm{m}^{-2} \mathrm{~d}^{-1}$ (Table 1$)$. This production is balanced by losses [721 $\left.( \pm 159) \mathrm{mg} \mathrm{C} \mathrm{m}^{-2} \mathrm{~d}^{-1}\right]$, and average NCP (over 4 days) is not significantly different from 0 . 
Table 1. Comparative carbon production and loss rates in the South Pacific Gyre.

\begin{tabular}{lllll}
\hline & \multicolumn{2}{c}{ Process measured } & \multicolumn{2}{c}{ Rate obtained } \\
\hline & Oxygen method & Optical method & Oxygen method & Optical method \\
Gains & $\mathrm{O}_{2}-\mathrm{GPP}$ & $\mathrm{Opt}_{\mathrm{GCP}}$ & $473 \pm 223$ & $734 \pm 97$ \\
Losses & $\mathrm{O}_{2}-\mathrm{CR}$ & $\mathrm{Opt}_{\mathrm{CL}}$ & $768 \pm 65$ & $721 \pm 159$ \\
Balance & $\mathrm{O}_{2}-\mathrm{NCP}$ & $\mathrm{Opt}^{\mathrm{NCP}}$ & $-295 \pm 158$ & $14 \pm 73$
\end{tabular}

Measurements were obtained using two techniques in the euphotic zone $(0-160 \mathrm{~m})$ at the GYR station. Values are expressed in $\mathrm{mg} C \mathrm{~m}^{-2}$ $\mathrm{d}^{-1} \pm$ one standard deviation. A photosynthetic and respiratory quotient of 1.1 is assumed (Laws, 1991). CR: Dark community respiration.

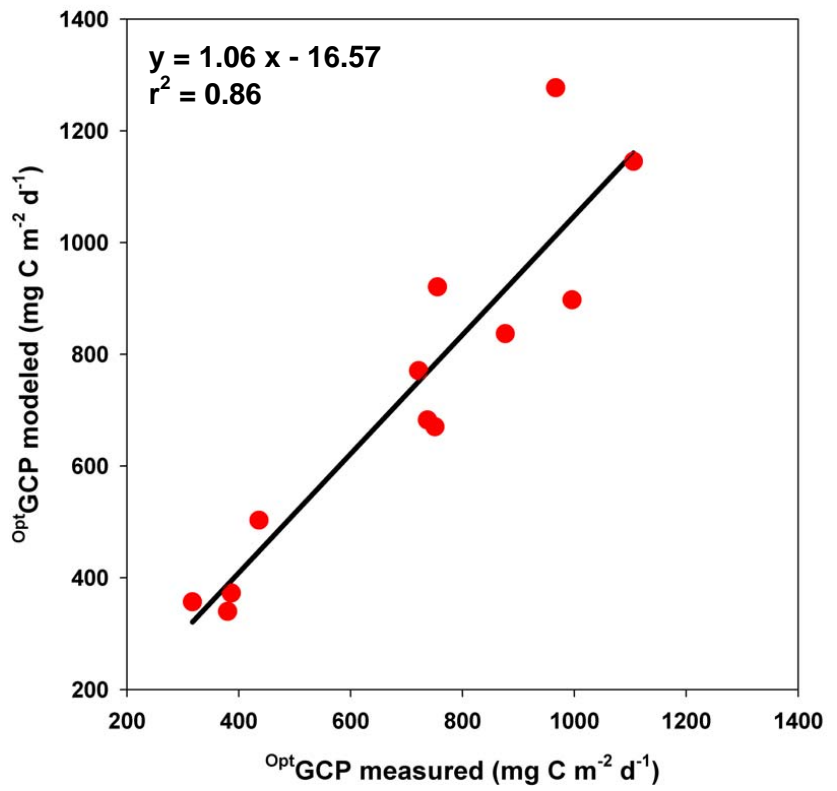

Fig. 7. Comparison of fitted (using the polynomial model) and measured ${ }^{\mathrm{Opt}} \mathrm{GCP}$ at the GYR station.

On days 1 and 3 , using classical measurements of $\mathrm{O}_{2}$ changes in light/dark bottles incubated over a 24-h period, Gross Primary Production $\left(\mathrm{O}_{2}-\mathrm{GPP}\right)$ and Community Respiration $\left(\mathrm{O}_{2}-\mathrm{CR}\right)$ were determined in the euphotic zone. $\mathrm{O}_{2}$ GPP, once converted to carbon units with a photosynthetic quotient of 1.1 (Laws, 1991), is significantly lower [473 ( \pm 223 ) $\mathrm{mg} \mathrm{C} \mathrm{m}^{-2} \mathrm{~d}^{-1}$ ] than GCP (Table 1). By contrast, and assuming a respiratory quotient of 1.1 , the $\mathrm{CR}$ of 768 ( \pm 65$) \mathrm{mg} \mathrm{C} \mathrm{m}^{-2} \mathrm{~d}^{-1}$ is in the same range as the loss rates determined by the optical method.

The net community production computed solely using $\mathrm{O}_{2}$ measurements leads to the usual conclusion that the upper ocean is in metabolic deficit $\left(\mathrm{O}_{2}-\mathrm{NCP}=-295( \pm 158) \mathrm{mg} \mathrm{C}\right.$ $\mathrm{m}^{-2} \mathrm{~d}^{-1}$ ) (Table 1). Being the most oligotrophic oceanic region, it is not surprising that our $\mathrm{O}_{2}$ based production rates are lower than those previously reported for the less oligotrophic North Pacific Gyre $\left[\mathrm{O}_{2}-\mathrm{GPP}=657( \pm 52) \mathrm{mg} \mathrm{C} \mathrm{m}^{-2}\right.$ $\mathrm{d}^{-1} ; \mathrm{O}_{2}-\mathrm{CR}=920( \pm 39) \mathrm{mg} \mathrm{C} \mathrm{m}^{-2} \mathrm{~d}^{-1}$ ] (Williams et al.,
2004). Our $\mathrm{O}_{2}-\mathrm{NCP}$ values for the $\mathrm{SPG}$ are however essentially equivalent to those for the North Pacific Gyre [-270 ( \pm 49$) \mathrm{mg} \mathrm{C} \mathrm{m}^{-2} \mathrm{~d}^{-1}$ ]. Contrary to incubation methods, our optical method is non-intrusive as are geochemical approaches. In addition, unlike geochemical observations, we integrate over the same time scales (hours to day) as incubation measurements.

When the model is applied to all oligotrophic stations (using only three measurements a day), the high ${ }^{\mathrm{Opt}} \mathrm{GCP}$ values recorded at GYR are confirmed (Fig. 8). On average, ${ }^{\mathrm{Opt}} \mathrm{GCP}$ amounts $452 \pm 264,846 \pm 484$ and $1093 \pm 520 \mathrm{mg} \mathrm{C} \mathrm{m}^{-2} \mathrm{~d}^{-1}$ for $0-0.5 \mathrm{Ze}, 0-\mathrm{Ze}$ and $0-1.5 \mathrm{Ze}$ layers, respectively. These high in situ estimates are comparable to the very high values of GPP (greater than $1 \mathrm{~g} \mathrm{~m}-2 \mathrm{~d}-1$ ) reported at station ALOHA using an in situ, non intrusive technique based on triple oxygen isotope measurements (Juranek and Quay, 2005). Our results when compared to other BIOSOPE results, remain, however, higher than primary production rates measured at the GYR station using $\mathrm{O}_{2}$ in vitro techniques. Furthermore these rates are much higher that the average rates derived for all the oligotrophic stations, using in vitro incubation with either ${ }^{13} \mathrm{C}$ labelling (Raimbault and Garcia, 2007: 180 $\pm 60 \mathrm{mg}$ $\mathrm{C} \mathrm{m}^{-2} \mathrm{~d}^{-1}$ ) or ${ }^{14} \mathrm{C}$ labelling (Van Wambeke et al., 2007 : $153 \pm 48 \mathrm{mg} \mathrm{C} \mathrm{m}^{-2} \mathrm{~d}^{-1}$ ). It should be noted, that contrarily to $\mathrm{O}_{2}$-based method, those measurements based on isotope labelling do not take into consideration Dissolved Organic Carbon (DOC) excretion, a process which can be of major significance in such systems (see later).

While optical measurements indicate that POC production is roughly balanced over 5 days, consistent with geochemical approaches, the oxygen measurements imply net heterotrophy. We argue below that photosynthetic processes occurring in extremely dim light conditions could explain, at least partly, the missing $\sim 300 \mathrm{mg} \mathrm{C} \mathrm{m}^{-2} \mathrm{~d}^{-1}$ estimated with $\mathrm{O}_{2}$ measurements (Table 1) to obtain the balanced production observed by the optical approaches.

Significant production rates were recorded in the deep layer (160-240 m) where the remaining light represents between $1 \%$ and $0.1 \%$ of surface radiation, i.e. below the so called euphotic zone (Table 2). A diurnal trend was not observed in this layer during our first day on station, which had experienced overcast conditions for at least 2 days (Fig. 4). 

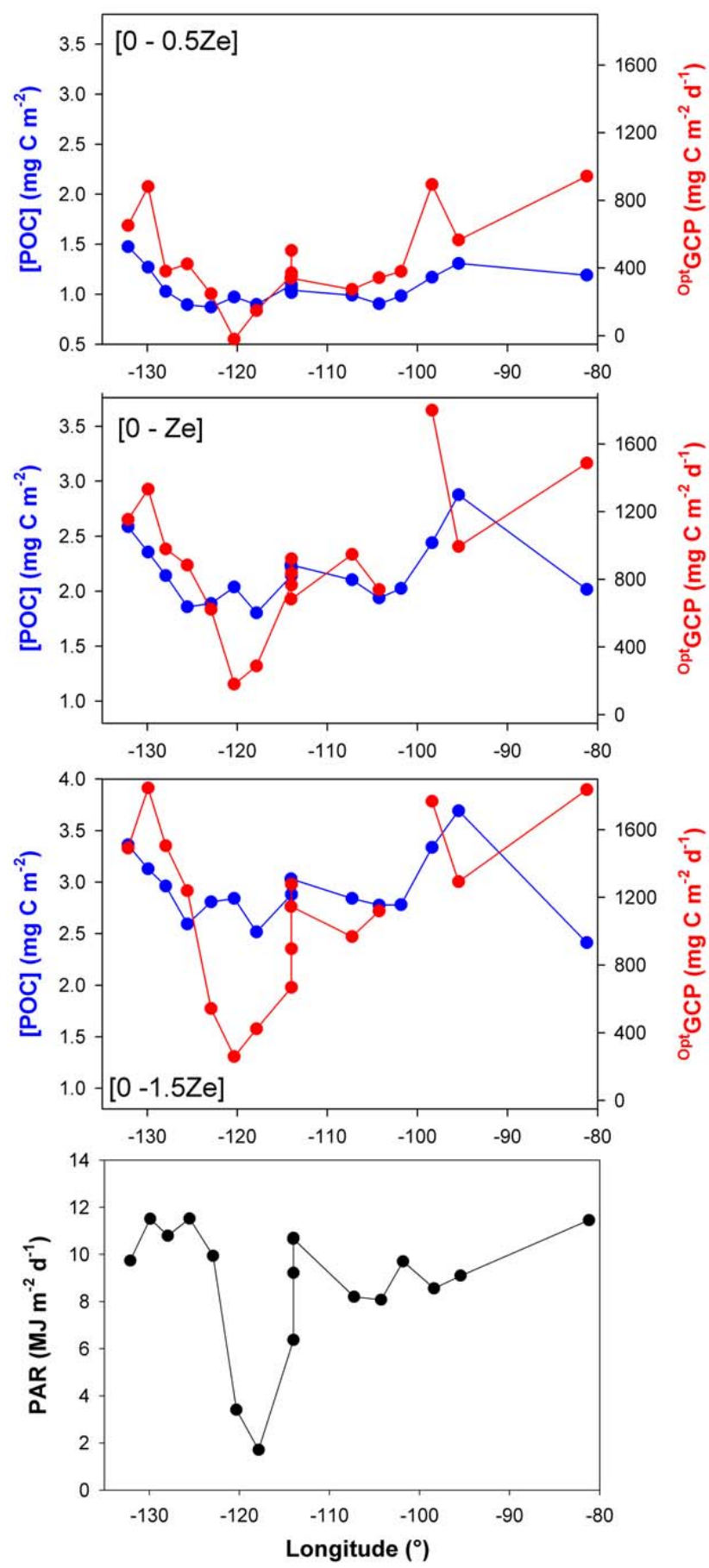

Fig. 8. Variations in $\mathrm{POC}$ and ${ }^{\mathrm{Opt}} \mathrm{GCP}$ in oligotrophic stations along the BIOSOPE transect. Only stations reported in red in Fig. 2 are here considered. The three upper panels corresponds to three different photic layers. The lower panel presents daily dose of PAR.

A clear cycle became apparent, however, in the last three days (13-15 November). SPG surface waters are the clearest of the global ocean (Morel et al., 2007a), and thus short term fluctuations in surface irradiance are reflected in the 160-
$240 \mathrm{~m}$ layer, and undoubtedly impact photosynthesis (and hence ${ }^{\mathrm{Opt}} \mathrm{GCP}$ ) at these depths. This process, although never demonstrated, was previously suggested for highly stratified oligotrophic systems (Karl et al., 2002). Actually in this deep layer, the ${ }^{\mathrm{Opt}} \mathrm{GCP}$ increased by a factor of seven over the four days of investigation (from $45 \mathrm{mg}$ to $319 \mathrm{mgC} \mathrm{m}^{-2} \mathrm{~d}^{-1}$ ) (Table 2). Over the same period, ${ }^{\mathrm{Opt}} \mathrm{GCP}$ in the euphotic zone increased by $34 \%$ reflecting to some extent saturation of photosynthesis at high light intensities. Furthermore, on some days (e.g. cycle 4), production in the deep layer could account for more than the average discrepancy between the oxygen and optical method observed for the $0-160 \mathrm{~m}$ layer. Over the 4 days of investigation, the mean ${ }^{\mathrm{Opt}} \mathrm{GCP}$ in this deep layer (176 $\mathrm{mg} \mathrm{C} \mathrm{m}^{-2} \mathrm{~d}^{-1}$, Table 2), which account for $\sim 60 \%$ of this discrepancy. About $40 \%$ of this discrepancy remains to be explained.

The concentration of dissolved organic carbon (DOC) in the euphotic layer $(\sim 120 \mu \mathrm{M})$ is the highest ever reported for a subtropical gyre (Raimbault et al., 2008). It is indeed about $20 \%$ higher than maximal values reported for the North Pacific Gyre (Church et al., 2002), and values as high as $90 \mu \mathrm{M}$ were still recorded at the $0.1 \%$ of surface radiation. Most of this DOC is likely of refractory nature and given the shape of the profile, these high concentrations must result from local production accumulating over time. For the North Pacific Gyre, it has been advanced that phototrophic production of DOC could represent up to 50\% of GPP (Karl et al., 1998). The optical method does not measure this dissolved fraction directly. However, in a tightly coupled system with a rapid turnover, the labile fraction of this dissolved production can fuel heterotrophic and photo-heterotrophic production in the SPG, especially during the daylight period (Church et al., 2004; Karl et al., 1998) and this production will be observed optically. We observed a peak in $c_{p}$ at $\sim 100 \mathrm{~m}$ that is not associated with any Chl- $a$ features (Fig. 2), and which shows clear daily oscillations and thus contribute to ${ }^{\mathrm{Opt}} \mathrm{GCP}$. This $c_{p}$ maximum is collocated with the BChl- $a$ maximum lying $80 \mathrm{~m}$ above the Chl- $a$ maximum (see also Ras et al., 2008), a feature present throughout a large part of the SPG. BChl- $a$-containing bacteria can use both light and dissolved organic material to sustain their growth and carbon requirements (Sieracki et al., 2006). Furthermore, besides photoheterotrophy performed by these BChl- $a$-containing bacteria, it is very likely that other photoheterotrophic organisms might intervene in particulate organic carbon build-up (Church et al., 2004; Beja et al., 2001). These processes might be particularly important in the nutrient impoverished environments of subtropical gyres (Karl, 2002).

The fact that, in these extremely clear oligotrophic waters, processes below the so-called euphotic zone (1\% depth) have not to date received much attention, might be surprising. Indeed, even if it is widely recognized that the deep chlorophyll maximum prevailing in oligotrophic gyre might be in large part the result of photo-adaptation processes, its presence nevertheless remains a clear indication that oxygen 
Table 2. Day-to-day variations in the carbon production and loss rates in the South Pacific Gyre.

\begin{tabular}{llllll}
\hline & ${ }^{\mathrm{Opt}} \mathrm{GCP}(0-240 \mathrm{~m})$ & ${ }^{\mathrm{Opt}} \mathrm{CL}(0-240 \mathrm{~m})$ & ${ }^{\mathrm{Opt}} \mathrm{NCP}(0-240 \mathrm{~m})$ & ${ }^{\text {Opt }} \mathrm{GCP}(160-240 \mathrm{~m})$ & Surface irradiance \\
\hline Cycle 1 & 663 & 607 & 56 & 45 & 26.6 \\
Cycle 2 & 920 & 881 & 39 & 123 & 44.5 \\
Cycle 3 & 911 & 888 & 23 & 219 & 38.4 \\
Cycle 4 & 1148 & 1211 & -63 & 319 & 44.4 \\
Mean & $910 \pm 198$ & $897 \pm 247$ & $14 \pm 53$ & $176 \pm 119$ & \\
\hline
\end{tabular}

The $240 \mathrm{~m}$ depth corresponds to 1.5 times the euphotic depth as traditionally defined, and is a depth where $0.1 \%$ of surface irradiance is available. Production terms are expressed in $\mathrm{mg} \mathrm{C} \mathrm{m}^{-2} \mathrm{~d}^{-1} \pm$ one standard deviation and surface irradiance in moles quanta $\mathrm{m}^{-2} \mathrm{~d}^{-1}$.

photosynthesis does occur in deep layers. Actually, at the GYR station, more than $60 \%$ of the water Chl- $a$ content was located in the layer comprised between the euphotic depth (Ze) and $1.5 \mathrm{Ze}$. The fact that other studies did not succeed to measure production $\left(\mathrm{O}_{2},{ }^{14} \mathrm{C}\right)$ in very deep layers (below $\mathrm{Ze}$ ) is very likely linked to the difficulty of keeping "deep samples" in extremely dim light (not to say dark) conditions during sample processing at sea. We suggest here that in most cases, deep populations receive unavoidable light damage during their sampling, manipulation and during bottle deployment at sea. Our optical method, operating at the same time scale than in vitro measurements, is not intrusive (like geochemical ones) and thus avoid any light hazard of that sort.

During the present investigation, surface irradiance varied tremendously, by a factor of 6 (more than the seasonal variation in surface irradiance) over 6 days. Nevertheless, the investigated area remained in metabolic balance (even in slight autotrophic state) which means that such highly stratified systems have a large capacity to adapt and to stabilize their metabolic status under strongly variable environmental conditions (here light, which is likely the most important forcing variable in subtropical oligotrophic gyres).

\section{Potential extrapolation of our observations}

The estimations based on the bio-optical method presented here were conducted at a location and period representative of the most extreme oligotrophic conditions of the global ocean (see supplementary information, part 1 http://www.biogeosciences.net/5/463/2008/ bg-5-463-2008-supplement.pdf). In this context, the rates estimated for this maximum of oligotrophy can be considered as a minimum reference for oligotrophic gyres in general ( $60 \%$ of the global ocean). From the Opt GCP rates measured $\left(846 \pm 484 \mathrm{mg} \mathrm{C} \mathrm{m}^{-2} \mathrm{~d}^{-1}\right)$ the annual carbon fixation rates for subtropical gyres are thus estimated to be at least $67 \mathrm{Pg}$ for the euphotic layer. These values are equivalent or higher than estimates derived from bio-optical models for the global ocean (Antoine et al., 1996; Behrenfeld et al., 2005).
The subtropical gyres, therefore, might have a much larger impact than anticipated on ocean carbon cycle.

Furthermore, we believe that the method presented here is potentially useful in the context of bio-optical modelling of production. Bio-optical models for the estimation of depth integrated primary production are of the general form :

$\mathrm{P}=\operatorname{PAR}\left(0^{+}\right) \times \mathrm{B} \times \Psi$

which expresses that the carbon fixation rate $\mathrm{P}\left(\mathrm{g} \mathrm{C} \mathrm{m}^{-2}\right.$ $\mathrm{d}^{-1}$ ) is proportional to the product of the column integrated content of the biomass (B) of phototrophic organism by the irradiance at the ocean surface, $\operatorname{PAR}(0+)$. B is generally depicted by areal Chl- $a$ (mg Chl- $\left.a \mathrm{~m}^{-2}\right) . \Psi$ is an efficiency term which convolves the irradiance absorption capability of B together with its efficiency in converting absorbed photons into chemical energy. Depending on the units chosen for PAR(0+) (quanta- or energy based), different ways of expressing $\Psi$ have been proposed (Falkowski, 1981; Malone, 1987; Morel, 1991). The most simple expression of $\Psi$ is achieved when B is expressed in terms of Chl- $a$ concentration and PAR(0+) is expressed in $\mathrm{MJ} \mathrm{m}^{-2} \mathrm{~d}^{-1}$ and converted into reduced carbon equivalent $\left(39 \mathrm{~kJ} \mathrm{gC}^{-1}\right)$ such that Eq. (7) can be rewritten as :

$\Psi^{*}=39 \mathrm{P} /\left[\operatorname{PAR}\left(0^{+}\right) \mathrm{Chl}-a\right]$

$\Psi^{*}\left(\mathrm{~m}^{2} \mathrm{~g} \mathrm{Chl}-a^{-1}\right)$ is here defined as the chlorophyll specific water column photosynthetic cross section. For the global ocean, within the layer comprised between the surface and $1.5 \mathrm{Ze}, \Psi^{*}$ varies within a relatively narrow range around a central value of $\Psi^{*}=0.070 \pm 0.035 \mathrm{~m}^{2} \mathrm{gChl}-$ $a^{-1}$. This means that $7 \%$ of the incident PAR is converted into stored chemical energy when $1 \mathrm{~g}$ of Chlorophyll- $a$ is present in the upper lit layers.

All the studies investigating such bulk water column efficiency indexes have only considered the biomass of photoautotrophic organisms depicted by Chl- $a$. The present study clearly demonstrates that phytoplankton alone cannot explain the daily increase in particulate carbon; heterotrophs (bacteria and possibly pico and nano-heterotrophs) as well as photo-heterotrophs also participate in this process. 

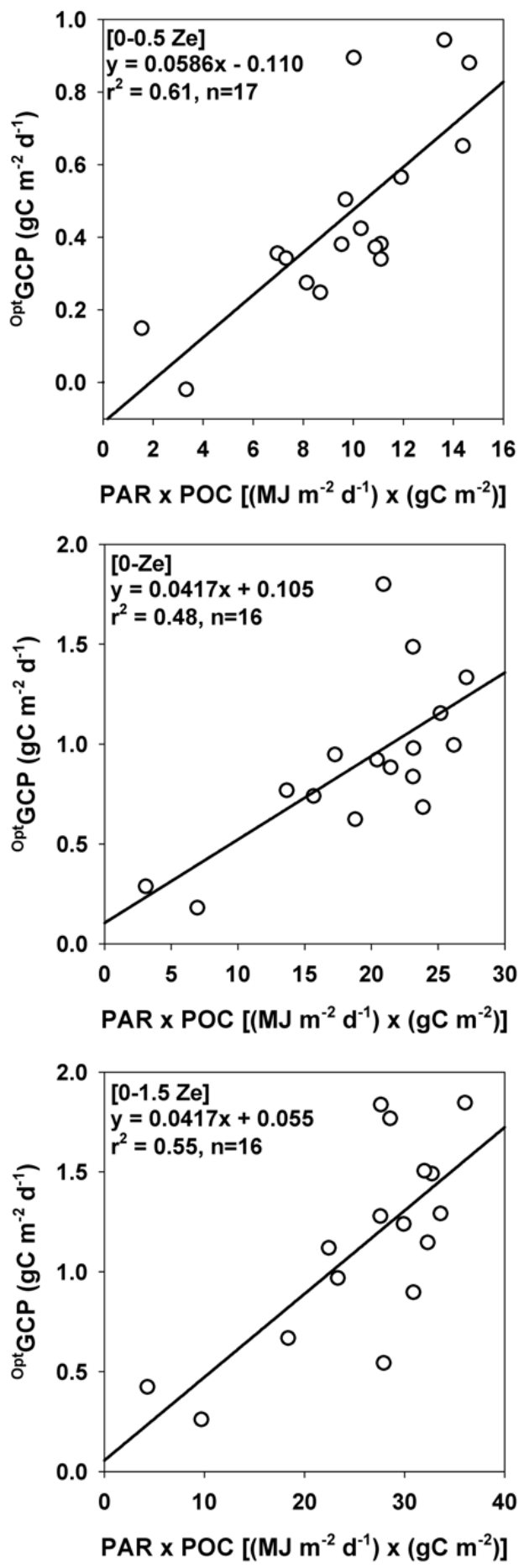

Fig. 9. The Estimation of $\psi^{*}{ }_{\mathrm{GCP}}$, the cross section for Growth Community Production in oligotrophic regime. $\psi^{*}$ GCP represents the slope of the regression between ${ }^{\mathrm{Opt}} \mathrm{GCP}$ and the product of surface irradiance by the carbon content. Data from station 13 have been excluded from this analysis for the $0-\mathrm{Ze}$ and $0-1.5 \mathrm{Ze}$ layer because internal waves have made the DCM (and the associated $c_{p}$ peak) shift from above Ze to below Ze between consecutive casts.
From Fig. 8, it is clear that ${ }^{\mathrm{Opt}} \mathrm{GCP}$ in all investigated layers appear to be reduced in the vicinity of $120^{\circ} \mathrm{W}$, when surface irradiance was drastically reduced $\left(2 \mathrm{MJ} \mathrm{m}^{-2} \mathrm{~d}^{-1}\right.$ vs. an average value over $10 \mathrm{MJ} \mathrm{m}^{-2} \mathrm{~d}^{-1}$ for the other stations). Figure 9 provides an analyses, for each layer, of the possible dependency of ${ }^{\mathrm{Opt}} \mathrm{GCP}$ with respect to biomass (here expressed in POC) and surface irradiance. Clearly ${ }^{\mathrm{Opt}} \mathrm{GCP}$ appears proportional to the product of POC and surface irradiance. This coupling suggests that, in the same way that a photosynthetic cross section was defined earlier, the Gross Community Production cross section with respect to carbon can be defined, $\Psi^{*}{ }_{\mathrm{GCP}}$ :

$$
\Psi^{*} \mathrm{GCP}=39^{\mathrm{Opt}} \mathrm{GCP} /\left[\mathrm{PAR}\left(0^{+}\right) \mathrm{POC}\right]
$$

Actually the slopes of the regression presented in Fig. 9 have units of $\mathrm{m}^{2} \mathrm{MJ}^{-1}$. Using the conversion factor (between energy and carbon), $\Psi^{*}{ }_{\mathrm{GCP}}$ is estimated to $2.2810^{-3}$, $1.6310^{-3}$ and $1.6310^{-3} \mathrm{~m}^{2} \mathrm{gC}^{-1}$ for $0-0.5 \mathrm{Ze}, 0-\mathrm{Ze}$ and $0-1.5 \mathrm{Ze}$ layers, respectively. In other words, $\sim 0.2 \%$ of the surface irradiance is converted to chemical energy when $1 \mathrm{~g}$ of POC is present. If the values are normalized by the generic $0.07 \mathrm{~m}^{2} \mathrm{~g} \mathrm{Chl}-a^{-1}$ for photosynthetic cross section a reasonable POC/Chl- $a$ ratio of $\sim 40$ is estimated within the $0-1.5 \mathrm{Ze}$ layer. This represents, at least, a partial validation of the estimations.

Beside the estimation of a carbon- rather than a Chl- $a$ based water column efficiency for production, the present approach has also a potential interest for the bio-optical modelling of production. Recently, it has been proposed that carbon-based, rather than Chl- $a$-based, models could be an improved way to estimate the rate of ocean carbon fixation from remote sensing data (Behrenfeld et al., 2005). The premise of carbon-based models is that the backscattering coefficient retrieved from space is an (accurate) estimation of phytoplankton carbon. This assumption is, however, questionable. Indeed, optical proxies (either $c_{p}$ or $b_{b p}$ ) derived from either space or in situ measurements are primarily related to the particle load (POC content in oceanic waters), including together with phytoplankton, heterotrophic components (bacteria, flagellates) and also bio-detritus; thus their relationship to phytoplankton carbon is not straightforward, if any.

Therefore, because community production likely integrates the contribution of all organisms depicted by $b_{b p}$, the proper rate of carbon fixation that should be associated with this optical proxy of particle load would better be the community production rather than the sole primary production. It is interesting to note that using the carbon-based model, Behrenfeld et al. (2005) ends up with much higher primary production rates for the tropical ocean than using a Chl- $a$ based model, while the discrepancies are much lower for other oceanic areas. One possibility for such discrepancies is that phytoplankton carbon derived from space would be overestimated in tropical environments ; some dedicated stud- 
ies have indeed clearly shown that the contribution of phytoplankton to $c_{p}$ can be low in such oligotrophic environment (Claustre et al., 1999). The production rates derived for these environments would possibly be more closely related to gross community (phytoplankton and small heterotrophs) rather than to primary production rates.

Based on the use of optical proxies of biogenic particles (not exclusively phytoplankton) from space, we thus believe that a bio-optical model of Gross Community Production (GCP) would thus likely provide a more reliable estimate of carbon fixation, especially in oligotrophic tropical environments where microbial communities play en essential role. Indeed, GCP is a photo-driven process which, besides the POC formation by phytoplankton, also integrates DOC excretion and its subsequent use by microbial organisms. DOC release is certainly a key process (see Karl et al., 1998) that would require much more attention in view of implementing such models.

Acknowledgements. We thank the captain and crew of the R/V Atalante for their pleasant cooperation during the BIOSOPE cruise. C. Marec is warmly thanked for their efficient help in CTD rosette management and data processing. We are grateful to D. Stramski for providing POC data used for the calibration of the attenuation coefficient. This is a contribution of the BIOSOPE project of the LEFE-CYBER program. This research was funded by the Centre National de la Recherche Scientifique (CNRS), the Institut des Sciences de l'Univers (INSU), the Centre National d'Etudes Spatiales (CNES), the European Space Agency (ESA), the National Aeronautics and Space Administration (NASA) and the Natural Sciences and Engineering Research Council of Canada (NSERC).

Edited by: E. Boss

\section{References}

Antoine, D., André, J. M., and Morel, A.: Oceanic primary production 2. Estimation at global scale from satellite (coastal zone color scanner) chlorophyll, Global Biogeochem. Cyc., 10, 5769, 1996.

Antoine, D., Morel, A., Gordon, H. R., Banzon, V. F., and Evans, R. H.: Bridging ocean color observations of the 1980's and 2000's in search of long-term trends, J. Geophys. Res., 110, C06009, doi:10.1029/2004JC002620, 2005.

Behrenfeld, M. J., Boss, E., Siegel, D. A., and Shea, D. M.: Carbon-based ocean productivity and phytoplankton physiology from space, Global Biogeochem. Cyc., 19, GB1006, doi:10.1029/2004GB002299, 2005.

Beja, O., Spudich, E. N., Spudich, J. L., Leclerc, M., and DeLong, E. F.: Proteorhodopsin phototrophy in the ocean, Nature, 411, 786-789, 2001.

Church, M. J., Ducklow, H., and Karl, D.: Multiyear increases in dissolved organic matter inventories at station ALOHA in the North Pacific Gyre, Limnol. Oceanogr., 47, 1-10, 2002.

Church, M. J., Ducklow, H. W., and Karl, D. A.: Light dependence of [H-3]leucine incorporation in the oligotrophic North Pacific ocean Appl. Environ. Microbiol., 70, 4079-4087, 2004.
Claustre, H. and Maritorena, S.: The many shades of ocean blue, Science, 302, 1514-1515, 2003.

Claustre, H., Morel, A., Babin, M., Cailliau, C., Marie, D., Marty, J. C., Tailliez, D., and Vaulot, D.: Variability in particle attenuation and chlorophyll fluorescence in the Tropical Pacific: Scales, patterns, and biogeochemical implications, J. Geophys. Res., 104, 3401-3422, 1999.

Claustre, H., Bricaud, A., Babin, M., Bruyant, F., Guillou, L., Le Gall, F., Marie, D., and Partensky, F.: Diel variations in Prochlorococcus optical properties, Limnol. Oceanogr., 47, 1637-1647, 2002.

Claustre, H., Sciandra, A., and Vaulot, D.: Introduction to the special section: bio-optical and biogeochemical conditions in the South East Pacific in late 2004 - the BIOSOPE program, Biogeosciences Discuss., 5, 605-640, 2008, http://www.biogeosciences-discuss.net/5/605/2008/.

Cullen, J. J., Lewis, M. R., Davis, C. O., and Barber, R. T.: Photosynthetic characteristics and estimated growth rates indicate grazing is the proximate control of primary production in the equatorial pacific, J. Geophys. Res., 97, 639-654, 1992.

del Giorgio, P. A. and Duarte, C. M.: Respiration in the open ocean, Nature, 420, 379-384, 2002.

del Giorgio, P. A., Cole, J. J., and Cimbleris, A.: Respiration rates in bacteria exceed phytoplankton production in unproductive aquatic systems, Nature, 385, 148, 1997.

Dietze, H. and Oschlies, A.: Modeling abiotic production of apparent oxygen utilisation in the oligotrophic subtropical North Atlantic, Ocean Dynam., 55, 28-33, 2005.

DuRand, M. D. and Olson, R. J.: Contributions of phytoplankton light scattering and cell concentration changes to diel variations in beam attenuation in the equatorial pacific from flow cytometric measurements of pico-, ultra- and nanoplankton, Deep-Sea Res. II, 43, 891-906, 1996.

DuRand, M. D., and Olson, R. J.: Diel patterns in optical properties of the chlorophyte nannochloris sp.: Relating individual-cell to bulk measurements, Limnol. Oceanogr., 43, 1107-1118, 1998.

Falkowski, P. G.: Light-shade adaptation and assimilation numbers, J. Plankton Res., 3, 203-216, 1981.

Gardner, W. D., Walsh, I. D., and Richardson, M. J.: Biophysical forcing of particle production and distribution during a spring bloom in the North Atlantic, Deep-Sea Res. Part II: Topical Studies in Oceanography, 40, 171-195, 1993.

Gardner, W. D., Mishonov, A. V., and Richardson, M. J.: Global POC concentrations from in-situ and satellite data, Deep-Sea Res. II: Topical Studies in Oceanography, 53, 718, 2006.

Grob, C., Ulloa, O., Claustre, H., Alarcon, G., Huot, Y., and Marie, D.: Contribution of picoplankton to the particulate attenuation coefficient (cp) and organic carbon concentration (POC) in the eastern South Pacific, Biogeosciences Discuss., 4, 837-852, 2007,

http://www.biogeosciences-discuss.net/4/837/2007/.

Gruber, N.: A bigger nitrogen fix, Nature, 436, 786, 2005.

Hansell, D., Ducklow, H., Macdonald, A. M., and O'Neil Baringer, M.: Metabolic poise in the north atlantic ocean diagnosed from organic matter transports, Limnol. Oceanogr., 49, 1084-1094, 2004.

Jenkins, W. J.: Oxygen utilization rates in North Atlantic subtropical gyre and primary production in oligotrophic systems, Nature, 300, 246-248, 1982. 
Jenkins, W. J.: Nitrate flux into the euphotic zone near Bermuda, Nature, 331, 521-523, 1988.

Juranek, L. W. and Quay, P. D.: In vitro and in situ gross primary and net community production in the North Pacific Subtropical Gyre using labeled and natural abundance isotopes of dissolved $\mathrm{O}_{2}$, Global Biogeochem. Cyc., 19, GB3009, doi:10.1029/2004GB002384, 2005.

Karl, D.: Hidden in a sea of microbes, Nature, 415, 590-591, 2002.

Karl, D., Bidigare, R. R., and Letelier, R.: Sustained and aperiodic variability in organic matter production and phototrophic microbial community structure in the North Pacific subtropical gyre, in: Phytoplankton productivity, Carbon assimilation in marine and freshwater ecosystems, edited by: P. J. L. Williams, D. N. Thomas, and C. S. Reynolds, Blackwell publishing, 222-264, 2002.

Karl, D., Laws, E. A., Morris, P., Williams, P. J. 1., and Emerson, S.: Metabolic balance of the open sea, Nature, 426, 32, 2003.

Karl, D. M., Hebel, D. V., Bjorkman, K., and Letelier, R. M.: The role of dissolved organic matter release in the productivity of the oligotrophic North Pacific Ocean, Limnol. Oceanogr., 43, 12701286, 1998.

Laws, E. A., Redalie, D. G., Haas, L. W., Bienfang, P. K., Eppley, R. W., Harrison, W. G., Karl, D. M., and Marra, J.: High phytoplankton growth and production rates in oligotrophic hawaiian coastal waters, Limnol. Oceanogr., 29, 1161-1169, 1984.

Laws, E. A.: Photosynthetic quotients, new production and net community production in the open ocean, Deep-Sea Res., 38, 143-167, 1991.

Lewis, M. R., Harrison, W. G., Oakey, N. S., Hebert, D., and Platt, T.: Vertical Nitrate Fluxes In The Oligotrophic Ocean, Science, 224, 870-873, 1986.

Loisel, H. and Morel, A.: Light scattering and chlorophyll concentration in case 1 waters: A reexamination, Limnol. Oceanogr., 43, 847-858, 1998.

Malone, T. C.: Primary production of the ocean water column as a function of surface light intensity, Deep-Sea Res., 34, 139, 1987.

Marra, J.: Primary production in the north atlantic: Measurements, scaling, and optical determinants, Philosophical Transactions of the Royal Society of London B, 348, 153-160, 1995.

Marra, J.: Capabilities and merits of long-term bio-optical moorings, in: Ocean optics, edited by: Spinrad, R. W., Carder, K. L., and Perry, M. J., Oxford University Press, New York, 189-201, 1994.

Marra, J.: Approaches for the measurement of plankton production, in: Phytoplankton productivity, Carbon assimilation in marine and freshwater ecosystems, edited by: Williams, P. J. L., Thomas, D. N., and Reynolds, C. S., Blackwell publishing, 78108, 2002.

Morel, A.: Optical modeling of the upper ocean in relation to its biogenous matter content (Case 1 waters), J. Geophys. Res., 93, 10749-10768, 1988.

Morel, A.: Light and marine photosynthesis: A spectral model with geochemical and climatological implications, Progress in Oceanography, 26, 263-306, 1991.

Morel, A., Gentili, B., Claustre, H., Babin, M., Bricaud, A., Ras, J., and Tieche, F.: Optical properties of the "clearest" natural waters, Limnol. Oceanogr., 52, 217-229, 2007 a.
Morel, A., Huot, Y., Gentili, B., Werdell, P. J., Hooker, S. B., and Franz, B. A.: Examining the consistency of products derived from various ocean color sensors in open ocean (Case 1) waters in the perspective of a multi-sensor approach, Remote Sensing of Environment, 111, 69-88, 2007b.

Oschlies, A.: Can eddies make ocean deserts bloom?, Global Biogeochem. Cy., 16, 1106, doi:10.1029/2001GB001830, 2002.

Raimbault, P., Garcia, N., and Cerrutti, F.: Distribution of inorganic and organic nutrients in the south pacific ocean -evidence for long-term accumulation of organic matter in nitrogen-depleted waters, Biogeosciences, 5, 281-298, 2008, http://www.biogeosciences.net/5/281/2008/.

Ras, J., Uitz, J., and Claustre, H.: Spatial variability of phytoplankton pigment distribution in the south east pacific, Biogeosciences, 5, 353-369, 2008, http://www.biogeosciences.net/5/353/2008/.

Siegel, D. A., Dickey, T. D., Washburn, L., Hamilton, M. K., and Mitchell, B. G.: Optical determination of particulate abundance and production variations in the oligotrophic ocean, Deep-Sea Res., 36, 211-222, 1989.

Sieracki, M. E., Gilg, I. C., Thier, E. C., Poulton, N. J., and Goericke, R.: Distribution of planktonic aerobic anoxygenic photoheterotrophic bacteria in the northwest Atlantic, Limnol. Oceanogr., 51, 38-46, 2006.

Stramski, D. and Kiefer, D. A.: Light scattering by microorganisms in the open ocean, Progress in Oceanography, 28, 343-383, 1991.

Stramski, D. and Reynolds, R. A.: Diel variations in the optical properties of a marine diatom, Limnol. Oceanogr., 38, 13471364, 1993.

Stramski, D., Shalapyonok, A., and Reynolds, R. A.: Optical characterization of the oceanic unicellular cyanobacterium Synechococcus grown under a day-night cycle in natural irradiance, J. Geophys. Res., 100, 13 295-13 307, 1995.

Stramski, D., Reynolds, R. A., Babin, M., Kaczmarek, S., Lewis, M. R., Rottgers, R., Sciandra, A., Stramska, M., Twardowski, M. S., and Claustre, H.: Relationships between the surface concentration of particulate organic carbon and optical properties in the eastern south pacific and eastern atlantic oceans, Biogeosciences, 5, 171-201, 2008, http://www.biogeosciences.net/5/171/2008/.

Van Wambeke, F., Obernosterer, I., Moutin, T., Duhamel, S., U1loa, O., and Claustre, H.: Heterotrophic bacterial production in the south east pacific: Longitudinal trends and coupling with primary production, Biogeosciences Discuss., 4, 2761-2791, 2007, http://www.biogeosciences-discuss.net/4/2761/2007/.

Vaulot, D., Marie, D., Olson, R. J., and Chisholm, S. W.: Growth of Prochlorococcus, a photosynthetic prokaryote, in the equatorial pacific ocean, Science, 268, 1480-1482, 1995.

Walsh, I. D., Chung, S. P., Richardson, M. J., and Gardner, W. D.: The diel cycle in the integrated particle load in the Equatorial Pacific: A comparison with primary production, Deep-Sea Res., 42, 465-477, 1995.

Williams, P. J. L., Morris, P. J., and Karl, D. M.: Net community production and metabolic balance at the oligotrophic ocean site, station ALOHA, Deep-Sea Res., 51, 1563-1578, 2004.

Williams, P. J. 1. B.: The balance of plankton respiration and photosynthesis in the open oceans, Nature, 394, 55-57, 1998. 